\title{
AMOUNT AND TYPE OF MICROBES ON THE COMMON CARP (Cyprinus carpio) IN JATILUHUR RESERVOIR WEST JAVA
}

\section{JUMLAH DAN JENIS MIKROBA PADA IKAN MAS (Cyprinus carpio) DI WADUK JATILUHUR JAWA BARAT}

\author{
Indah Nurwulan ${ }^{1}$, Eddy Afrianto ${ }^{2}$, Iis Rostini ${ }^{2}$, Rusky Intan Pratama ${ }^{2}$ \\ 1Program Studi Perikanan, Fakultas Perikanan dan Ilmu Kelautan Universitas Padjadjaran Jalan Raya Bandung-Sumedang \\ km 21 Jatinangor 40600 Sumedang Jawa Barat \\ 2Program Studi Perikanan, Fakultas Perikanan dan Ilmu Kelautan Universitas Padjadjaran Jalan Raya Bandung-Sumedang \\ km 21 Jatinangor 40600 Sumedang Jawa Barat \\ Correspondence Author : indahnurwulan910@gmail.com
}

\begin{tabular}{ll}
\hline I N F O A R T I E L & A B S T R A C T \\
\hline Diterima: & This research was conducted in Microbiology Laboratory of Biology Department, \\
Disetujui: & Faculty of Mathematics and Natural Sciences, Padjadjaran University in May \\
Kata kunci: & 2017. The purpose of the research was to identify the number and types of \\
Jatiluhur Reservoir & microbes contained in carp (Cyprinus carpio) in Jatiluhur Reservoir, West Java. \\
& The method used in this research was sample survey method or field survey. The \\
water and common carp sampling stations are divided into 3 stations, station 1 is \\
located in Zone 1 (low density), station 2 is located in Zone 3 (medium density), \\
and station 3 is located in Zone 5 (high density). Determination of sampling \\
location water and fish is done based on Data Recapitulation of Density of \\
Karamba Floating Net from the Department of Animal Husbandry and Fisheries of \\
West Java. Water samples and fish mucus were tested using Total Plate Count \\
(TPC) method using different specific media that is Trypticase Soy Agar (TSA), \\
deMann Ragosa Sharpe Agar (MRSA), Kliger Iron Agaar (KIA), Thiosulphate \\
Citrate Bile salts Sucrose Agar (TCBS), and Xylose Lysine Deoxycholate (XLD). \\
Microbes can be known by species because they just grown on specific media that \\
can directly showed the specific characteristics of certain microbial species based \\
on the color of the colony. The parameter observed were microbiological test \\
(TPC). The result of the research showed that there was Bacillus sp, Escherichia \\
coli, Lactobacillus sp, Vibrio cholerae, Vibrio parahemoliticus, Vibrio spp, dan \\
Shigella sp on the water samples and carp mucus. The result of research on water \\
samples and fishery products in Jatiluhur Reservoir showed that water quality in \\
Zone 1, Zone 3, and Zone 5 is still below the threshold of microbial contamination \\
based on SNI 7388: 2009, while fish located in Zone 3 and Zone 5 is contaminated \\
by Escherecia coli and Vibrio cholerae, exceed the threshold of SNI 7388: 2009 on \\
microbial contamination in fresh fish.
\end{tabular}

\section{PENDAHULUAN}

Waduk Jatiluhur (Ir. H. Juanda) merupakan waduk yang dibangun di daerah aliran sungai (DAS) Citarum dengan tujuan sebagai Pembangkit Listrik Tenaga Air (PLTA), penyediaan air minum, sebagai pencegah banjir, dan kegiatan perikanan berupa Karamba Jaring Apung. Pola budidaya ikan di waduk ini dilakukan dengan menggunakan sistem Keramba Jaring Apung (KJA) berukuran 7x7 meter. 
Jenis ikan yang dibudidayakan adalah jenis ikan mas, nila dan patin. Menurut Koeshendraja (2011), ada beberapa faktor yang menyebabkan produktivitas usaha budidaya ikan di Waduk Jatiluhur selalu mengalami penurunan, antara lain yang utama adalah penurunan kualitas air akibat limbah organik yang timbul dari pakan yang diberikan, semakin bertambahnya jumlah KJA, benih ikan serta kualitas pakan.

Penurunan kualitas air di Waduk Jatiluhur ini disebabkan oleh beberapa faktor, salah satunya adalah limbah sisa pakan KJA. Jumlah Karamba Jaring Apung di Waduk Jatiluhur berdasarkan data pemerintah daerah pada tahun $2016 \pm 23.000 \mathrm{KJA}$, sedangkan jumlah KJA yang ideal berdasarkan keputusan Bupati Purwakarta No. 6 Tahun 2000 tentang Pemanfaatan Waduk untuk kegiatan perikanan, jumlah ideal KJA di waduk seluas 8.300 ha itu adalah 2.100 petak.

Dampak negatif akan terjadi melihat dari jumlah KJA yang tidak sesuai dengan peraturan yang ada, salah satunya adalah banyaknya jumlah limbah sisa pakan yang dihasilkan oleh KJA dan dapat menurunkan kualitas air waduk. Keadaan perairan tersebut dapat memungkinkan mikroba merugikan untuk tumbuh dan berkembangbiak. Munculnya mikroba dipengaruhi oleh adanya nutrient, air, $\mathrm{pH}$, suhu, kadar oksigen, potensial oksidasi - reduksi, dan adanya zat penghambat (MacFaddin 2000).

Ikan yang baru ditangkap mengandung mikroba secara alami dimana mikroba tersebut terkonsentrasi pada tiga bagian utama yaitu : permukaan kulit, insang dan isi perut. Jumlah bakteri pada ikan bervariasi tergantung media dimana bakteri itu hidup (Taher 2010). Kandungan air dan protein yang tinggi pada tubuh ikan, merupakan media yang cocok untuk pertumbuhan bakteri pembusuk atau mikroorganisme yang lain, sehingga ikan sangat cepat mengalami proses pembusukan dan menjadi tidak segar lagi. Perkembangan mikroba pada ikan umumnya terdapat pada bagian lendir dan kulit, di dalam suatu bagian lendir dan kulit terdapat sekumpulan jenis - jenis mikroba patogen maupun mikroba menguntungkan (Adam dan Moss 2008).

Ikan Mas merupakan salah satu ikan yang dibudidayakan di KJA Waduk Jatiluhur, dan termasuk salah satu ikan konsumsi yang digemari oleh masyarakat Indonesia. Volume produksi budidaya ikan mas di Jawa Barat merupakan yang tertinggi di Indonesia. Total volume produksi budidaya ikan mas di Jawa Barat pada tahun 2013 sebanyak 167.390 ton, dan merupakan produksi tertinggi dibandingkan dengan 9 provinsi lainnya (KKP 2013). Berdasarkan hal tersebut, dilakukan penelitian mengenai identifikasi jumlah dan jenis mikroba pada ikan mas (Cyprinus carpio) di Waduk Jatiluhur. Penelitian ini bertujuan untuk mengidentifikasi jumlah dan jenis mikroba yang terdapat pada ikan mas (Cyprinus carpio) di Waduk Jatiluhur.

\section{METODE PENELITIAN}

Penelitian ini akan dilaksanakan pada bulan Mei 2017. Pengambilan sampel dilakukan di Waduk Jatiluhur Purwakarta Jawa Barat, dan analisis dilakukan di laboratorium mikrobiologi, Fakultas Matematika dan Ilmu pengetahuan alam (FMIPA) Universitas Padjadjaran (UNPAD). Metode penelitian yang digunakan dalam penelitian ini adalah sample survey method atau survei di lapangan, yaitu suatu survei yang tidak akan meneliti semua individu dalam sebuah populasi, namun hasil yang diharapkan harus dapat menggambakan sifat dari populasi yang bersangkutan.

Pengambilan sampel ikan dilakukan pada perairan yang merupakan pusat kegiatan keramba jaring apung (KJA) di Waduk Jatiluhur yang terbagi atas 3 stasiun pengambilan sampel berdasarkan kepadatan KJA yang berbeda. Stasiun 1 berlokasi di Zona 1(kepadatan rendah), stasiun 2 berlokasi di Zona 3 (kepadatan sedang), dan stasiun 3 berlokasi di Zona 5 (kepadatan tinggi). Penentuan Zona kepadatan KJA dilakukan berdasarkan Rekapitulasi Data Kepemilikan KJA Waduk Jatiluhur dari Dinas Peternakan dan Perikanan Purwakarta Jawa Barat periode Juli s/d Desember 2014.

\section{HASIL DAN PEMBAHASAN}

\section{Hasil Identifikasi Jumlah dan Jenis Koloni Bakteri}

Identifikasi mikroba pada sampel air dan lendir ikan mas ditentukan berdasarkan zona keramba jaring apung yang terdapat di Waduk Jatiluhur. Pengambilan sampel didasarkan oleh tingkat kepadatan KJA yang berbeda yakni rendah, sedang, dan tinggi yang terletak pada Zona 1 (rendah), Zona 3 (sedang), dan Zona 5 (tinggi) dan di uji menggunakan metode Total Plate Count (TPC) dengan medium spesifik. Hasil pengamatan selama penelitian mendapatkan bakteri yang tumbuh pada sampel air dan lendir ikan mas (Cyprinus carpio) dapat dilihat pada Tabel 1. 
Tabel 1. Jenis dan Jumlah Koloni Bakteri (Cfu/Gram) pada Air dan Lendir Ikan

\begin{tabular}{|c|c|c|c|c|c|c|}
\hline \multirow{2}{*}{ Jenis Bakteri } & \multicolumn{3}{|c|}{ Sampel air } & \multicolumn{3}{|c|}{ Sampel lendir ikan mas } \\
\hline & Zona 1 & Zona 3 & Zona 5 & Zona 1 & Zona 3 & Zona 5 \\
\hline Bacillus sp & $4,8 \times 10^{5}$ & $1,2 \times 10^{6}$ & $1,1 \times 10^{6}$ & $3,2 \times 10^{6}$ & $1,7 \times 10^{6}$ & $7,1 \times 10^{5}$ \\
\hline Escherichia coli & - & $2,5 \times 10^{3}$ & $1,52 \times 10^{4}$ & $1,42 \times 10^{4}$ & - & $>3,0 \times 10^{4}$ \\
\hline Lactobacillus sp & $1,0 \times 10^{4}$ & - & - & - & $8,6 \times 10^{4}$ & - \\
\hline $\begin{array}{c}\text { Vibrio cholerae } \\
\text { Vibrio }\end{array}$ & $2,8 \times 10^{2}$ & $6,6 \times 10^{2}$ & $3,0 \times 10^{2}$ & $2,72 \times 10^{3}$ & $>3,0 \times 10^{3}$ & $1,49 \times 10^{3}$ \\
\hline parahaemoliticus & $1,2 \times 10^{2}$ & - & - & - & - & $2,3 \times 10^{2}$ \\
\hline Vibrio spp & - & - & - & - & $3,1 \times 10^{2}$ & $1,08 \times 10^{3}$ \\
\hline Shigella $\mathrm{sp}$ & $2,2 \times 10^{2}$ & $5,0 \times 10^{2}$ & $2,1 \times 10^{2}$ & $5,0 \times 10^{2}$ & $1,21 \times 10^{3}$ & $4,0 \times 10^{1}$ \\
\hline
\end{tabular}

Keterangan ( - ) : Tidak ditemukan bakteri

\section{Sampel Air di KJA Waduk Jatiluhur}

Hasil uji identifikasi mikroba pada sampel air di 3 Zona yang berbeda,yakni pada Zona 1, Zona 3, dan Zona 5 berdasarkan kepadatan jumlah keramba jaring apung (KJA) menunjukkan adanya bakteri patogen dan bakteri probiotik yang terdapat pada sampel air tersebut. Terdapat 5 jenis bakteri patogen dan 2 jenis bakteri probiotik, bakteri patogen yang dimaksud yakni Escherichia coli, Vibrio cholera, Vibrio parahaemoliticus, Vibrio Spp, dan Shigella sp. sedangkan untuk bakteri probiotik yaitu Bacillus sp. dan Lactobacillus sp.

Berdasarkan hasil identifikasi bakteri dari ketiga Zona, dapat dilihat bakteri yang dominan pada ketiga zona tersebut adalah bakteri Bacillus sp, menurut Holtj et al. (1994) Bacillus sp. Merupakan bakteri Gram positif, endospora oval, terkadang bundar atau silinder dan sangat resisten pada kondisi yang tidak menguntungkan. Bakteri ini tersebar luas pada bermacam-macam habitat, bakteri ini tidak bersifat patogen terhadap vertebrata atau invertebrata (Feliatra $d k k$ 2004).

Keberadaan bakteri Bacillus sp yang dominan diperairan pada Zona 1, Zona 3 dan Zona 5 dikarenakan bakteri ini merupakan bakteri yang secara alamiah berada pada perairan. Bakteri Bacillus sp merupakan jenis bakteri detritus yaitu bakteri yang mempunyai sifat sebagai perombak bahan organik diantaranya senyawa nitrogen dan selanjutnya melalui proses nitrifikasi membentuk nitrat (Linggarjati 2013), bakteri ini juga membantu menguraikan selulosa sehingga bahan organik dapat terurai (Ardilawati 2013). Keberadaan bakteri Bacillus sp yang cukup tinggi pada sampel air dari ke tiga zona (Tabel 1) menandakan bahwa kandungan bahan organik yang ada pada waduk Jatiluhur cukup tinggi, sehingga dengan keadaan lingkungan tersebut membuat bakteri Bacillus sp mudah tumbuh. Berdasarkan sumbernya bahan organik di Waduk Jatiluhur dapat berasal dari ekosistem lain (allochthonous) maupun dari dalam waduk itu sendiri (autochthonous). Bahan organik yang berasal dari luar waduk misalnya limbah industri, limbah pertanian, dan termasuk limbah dari kegiatan budidaya karamba jaring apung. Dengan adanya bakteri Bacillus sp pada perairan, dapat mengurangi kadar bahan organik pada perairan tersebut karena Bacillus sp mempunyai sifat sebagai perombak bahan organik.

Selain bakteri Bacillus sp. terdapat bakteri probiotik lainnya yaitu bakteri Lactobacillus sp. yang terdapat pada sampel air di Zona 1 dengan nilai yang cukup tinggi dengan jumlah koloni $1,0 \mathrm{x}$ $10^{4} \mathrm{cfu} / \mathrm{gram}$, dan bakteri tersebut tidak terdapat di sampel air zona 3 dan 5 . Hal ini dikarenakan Zona 1 memiliki pola arus yang cenderung memutar, sehingga bakteri Lactobacillus yang berada di zona tersebut tidak menyebar dan hanya menetap di Zona itu saja. Sedangkan Zona 3 memiliki pola arus yang cenderung menuju ke bagian hilir Waduk dan Zona 5 memiliki pola arus yang cenderung memutar (Harsono 2016). Bakteri Lactobacillus sp yang tidak teridentifikasi pada Zona 5 dikarenakan para pembudidaya tidak memberikan probiotik pada air ataupun pakan yang digunakan pada ikan yang dibudidayakan, sehingga bakteri Lactobacillus tidak teridentifikasi pada sampel air maupun lendir ikan di Zona 5. 
Keberadaan bakteri Lactobacillus sp diperairan juga merupakan hasil dari rekayasa para pembudidaya ikan di KJA untuk menghasilkan kualitas ikan yang baik serta menjaga kualitas lingkungan agar tetap terjaga. Bakteri Lactobacillus sp yang berada pada sampel air (Tabel 1) dihasilkan dari pencampuran pakan ikan dengan probiotik, serta biasanya para pembudidaya meneteskan probiotik pada kolam karamba jaring apung setiap dua minggu sekali. Menurut Mansyur dan Tangko (2008) ada dua macam cara aplikasi probiotik pada budidaya ikan, yang pertama dengan cara mencampurkan probiotik dengan pakan dan yang kedua melalui lingkungannya yaitu dengan cara menuangkan probiotik pada air kolam budidaya. Frekuensi pemberian probiotik pada kolam budidaya karamba jaring apung minimal dua minggu sekali dan bisa dilakukan setaip saat jika ikan mengalami stress dan nafsu makan menurun, maupun pada saat kondisi lingkungan yang buruk seperti air yang sudah keruh atau berbau.

Hasil identifikasi sampel air pada Zona 3 dan Zona 5 terdapat bakteri Escherechia coli (Tabel 1) dimana bakteri tersebut berasal dari kotoran manusia atau hewan (feses). Namun pada Zona 1 tidak teridentifikasi adanya bakteri E.coli dikarenakan pada Zona 1 terdapat jenis bakteri probiotik yaitu Lactobacillus sp yang mendominasi dan dapat menghambat pertumbuhan bakteri patogen seperti bakteri E.coli. Menurut Rostini (2007) bakteri probiotik merupakan bakteri yang mampu berkompetisi dengan bakteri patogen sehingga dapat menghambat pertumbuhan bakteri patogen dan bakteri pembusuk.

\section{Sampel Lendir Ikan di KJA Waduk Jatiluhur}

Berdasarkan hasil identifikasi sampel lendir ikan mas (Tabel 1), terdapat beberapa jenis bakteri yang ada pada sampel air namun tidak ada pada sampel lendir ikan. Hal tersebut dikarenakan bakteri yang berada pada bagian lendir ikan tidak terlalu banyak jumlahnya dibandingkan dengan bakteri yang ada pada insang dan usus ikan. Ikan yang ditangkap pada perairan hanya mengandung sedikit mikroba pada permukaannya, kebanyakan kontaminasi bakteri pada ikan adalah pada saat pendaratan ikan dan juga proses penanganan serta pada saat proses penyimpanan (Alfred 1998).

Bakteri Escherichia coli yang teridentifikasi pada Zona 3 yang ada pada sampel air, namun tidak ada pada sampel lendir ikan di Zona 3 dikarenakan pada sampel lendir ikan Zona 3 terdapat bakteri Lactobacillus dengan jumlah 8,6 x $10^{4} \mathrm{cfu} / \mathrm{gram}$, dimana bakteri tersebut merupakan bakteri yang dapat menghasilkan asam laktat dan peroksidase yang dapat menghambat berbagai macam mikroba patogen, sehingga bakteri $E$. coli tidak teridentifikasi pada sampel lendir ikan di Zona 3. Ada tiga mekanisme bakteri Lactobacillus dalam menghambat aktivitas mikroba patogen yaitu menimbulkan persaingan makanan sedemikian rupa sehingga bakteri patogen sulit untuk mendapatkan makanan, menurunkan $\mathrm{pH}$ lingkungan sehingga aktivitas bakteri patogen terganggu dan tidak dapat bertahan hidup, dan menghasilkan produk metabolit yang bersifat racun bagi bakteri merugikan (Malaka $d k k$. 2005). Jumlah bakteri Lactobacillus yang cukup tinggi pada sampel lendir ikan di Zona 3 dikarenakan pada saat pengambilan sampel, ikan uji baru diberikan pakan yang sebelumnya telah dicampurkan bakteri Lactobacillus sehingga bakteri tersebut melekat pada lendir ikan mas.

Pada zona 3 dan 5 terdapat bakteri Vibrio cholerae dan E. coli yang nilainya mencapai $>3,0$ cfu/gram, hal tersebut menunjukan bahwa cemaran bakteri pada sampel lendir ikan mas sudah melebihi ambang batas yang telah ditentukan oleh SNI 7388:2009 yaitu setiap $1 \mathrm{~g}$ sampel ikan segar tidak boleh ditemukannya 1 koloni bakteri (E.coli $<3$ koloni/g). Teridentifikasinya bakteri E. coli dan V. cholerae yang melebihi ambang batas dikarenakan pada Zona 3 dan Zona 5 memiliki kepadatan KJA yang tinggi yaitu sebanyak 3.950 petak (Zona 3) dan 17.058 petak (Zona 5). Hal tersebut menandakan bahwa semakin tinggi suatu kepadatan KJA, maka semakin besar pula koloni bakteri yang tumbuh didalamnya. Penyebab timbulnya bakteri E.coli dan V. cholerae yaitu adanya cemaran yang berasal dari kotoran manusia dan hewan yang termasuk kedalam bakteri coliform. Salah satu indikator pencemaran mikrobia adalah keberadaan bakteri coliform. Bakteri coliform ada yang bersifat patogen yaitu bakteri yang dapat menimbulkan penyakit. Bakteri coliform berdasarkan asal dan sifatnya dapat dibedakan menjadi 2 kelompok yaitu kelompok fecal (E.coli) yang berasal dari tinja manusia dan non fecal (Enterobacter aerogenus) yang bukan berasal dari tinja manusia, tetapi mungkin berasal dari sumber lain (Suriawaria 1993).

Bakteri Vibrio cholerae merupakan salah satu mikroba penyebab penyakit yang sering ditemukan pada makanan. Bila bakteri ini mencemari makanan dan terkonsumsi dalam jumlah tertentu, maka dapat menyebabkan penyakit kolera. Menurut Osawa (2008) bakteri V. cholerae penyebarannya dapat berasal dari hasil perikanan yang terkontaminasi bakteri patogen tersebut. Keberadaan bakteri Vibrio sp yang mengkontaminasi perairan diduga dapat menyebabkan infeksi pada 
ikan yang hidup diperairan tersebut (Syawal 2016). Hasil identifikasi bakteri pada sampel ikan di Zona 3 (Tabel 2) menunjukan nilai bakteri $V$. cholerae sebanyak $>3,0 \times 10^{3} \mathrm{cfu} / \mathrm{gram}$, hal tersebut menandakan bahwa ikan pada Zona 3 sudah tercemar oleh feses sehingga tidak layak untuk dikonsumsi.

Berdasarkan Surat Keputusan Dirjen Pengawasan Obat dan Makanan (POM) Nomor HK.00.06.1.52.4011 tentang penetapan batas maksimum cemaran mikroba dan kimia dalam makanan, apabila terdapat bakteri Vibrio cholerae pada ikan dan produk perikanan lainnya melebihi batas yang ditentukan yaitu $5 \times 10^{5} \mathrm{koloni} / \mathrm{g}$ maka makanan tersebut tidak memenuhi syarat kesehatan walaupun jumlahnya belum dapat menimbulkan penyakit pada manusia. Berdasarkan peraturan tersebut maka ikan yang berada di Zona 3 sudah tidak layak untuk dikonsumsi, dan dapat membahayakan manusia yang mengkonsumsinya.

\section{KESIMPULAN}

Berdasarkan hasil identifikasi bakteri yang dilakukan pada air dan ikan mas yang berasal dari Waduk Jatiluhur, maka dapat ditarik beberapa kesimpulan mengenai jumlah dan jenis mikroba pada ikan mas (Cyprinus carpio) di Waduk Jatiluhur, yaitu :

1. Terdapat beberapa jenis mikroba pada setiap zona yang telah diidentfikasi berdasarkan uji Total Plate Count (TPC), bakteri tersebut diantaranya adalah Bacillus sp, Escherichia coli, Lactobacillus sp, Vibrio Cholerae, Vibrio parahemoliticus, Vibrio spp, dan Shigella sp.

2. Bakteri yang mendominasi dikedua sampel yakni bakteri Bacillus sp, hal tersebut menunjukan bahwa kualitas air pada Zona 1, Zona 3, dan Zona 5 masih dibawah ambang batas SNI 7388:2009, sedangkan untuk ikan yang berada di Zona 3 dan 5 sudah tercemar oleh bakteri Escherecia coli dan Vibrio cholerae yang melebihi ambang batas berdasarkan SNI 7388:2009 mengenai cemaran mikroba pada ikan segar.

\section{REKOMENDASI}

Berdasarkan hasil penelitian dapat disarankan untuk mengidentifikasi mikroba pada bagian usus, dan insang ikan. Karena bakteri yang terdapat pada lendir ikan tidak terlalu banyak dibandingkan dengan jumlah bakteri yang berada pada isi perut dan insang ikan.

\section{DAFTAR PUSTAKA}

Adam MR and Moss OM. 2008. Food Microbiology. Third Edition. p: 139-145. The Royal Society of Chemistry, United Kingdom.

Alfred A. 1998. The Effect of Delayed Icing and Gutting on The Quality of Freshwater Arctic Charr (Salvelinus alpinus L.).United Nation University-Fisheries Training Programe. Iceland.

Ardilawati, L. 2013. Pengaruh Pemberian Probiotik Berbeda pada Pakan Komersil Terhadap Retensi Protein, Lemak, dan Energi Ikan Lele Sangkuriang (Clarias sp). Skripsi. Fakultas Perikanan dan Ilmu Kelautan. Universitas Airlangga. Surabaya. 67 Hal.

Badan Pengawas Obat dan Makanan Republik Indonesia. Peraturan Kepala Badan POM No. HK.00.06.1.52.4011 Tentang Penetapan Batas Maksimum Cemaran Mikroba dan Kimia dalam Makanan.

Badan Standarisasi Nasional Republik Indonesia. 2009. Batas Maksimum Cemaran Mikroba Dalam Pangan. SNI 7388:2009. Jakarta.

Dinas Peternakan dan Perikanan Purwakarta Jawa Barat. Rekapitulasi Data Kepemilikan KJA Di Waduk Jatiluhur Berdasarkan Hasil Pengecekan Lapangan s/d 31 Desember 2014. Purwakarta. Jawa Barat.

Harsono, E. 2016. Model Eutrofikasi 2-Dimensi Berlapis untuk Optimalisasi Lokasi Zona Budidaya Ikan Karamba Jaring Apung (KJA) Di Waduk Jatiluhur. Jurnal Biologi Indonesia. Vol 12 (1): 277-289. 
Holt, J.G., N.R. Krieg, P.H.A. Sneath, J.T. Staley, dan S.T. Williams. 1994. Bergey's Manual of Determinative Bacteriology. Ninth Edition. Williams and Wilkins. Baltimore, Maryland.

Https://www.djpb.kkp.go.id/public/upload/.../LAPTAH\%20PRODUKSI\%20\%202013. (Diakses pada tanggal 17 Februari 2017 pukul 17.09 WIB)

Feliatra., I. Effendi, dan E. Suryandi. 2004. Isolasi dan Identifikasi Bakteri Probiotik dari Ikan Kerapu Macan (Ephinephelus fuscogatus) dalam Upaya Efisiensi Pakan. Jurnal Natur Indonesia. Vol $\mathrm{VI}: 75-80$.

[http://www.unri.ac.id/jurnal/jurnal_natur/vol6(2)_Feliatra. Di Unduh 2 Agustus 2017; 14.30 WIB].

Koeshendrajana, S. dkk. 2011. Penebaran Ikan Bandeng Di Waduk Jatiluhur : Analisis Dampak dan Kebijakan Pengembangan. Jurnal Kebijakan Sosial Ekonomi Kelautan dan Perikanan. Vol. 1(1): $17 \mathrm{hlm}$.

Linggarjati, KF., A Djunaedi, Subagiyo. 2013. Uji Penggunaan Bacillus sp Sebagai Kandidat Probiotik untuk pemeliharan Rajungan (Portunus sp). Journal of Marine Research. Vol 2(1): $6 \mathrm{hlm}$.

MacFaddin JF. Urease Test. Biochemical Tests for Identification of Medical Bacteria. 3rd ed. Lippincott Williams and Wilkins; Philadelphia:2000. p. 424-38.

Mansyur, A dan A. M Tangko. Probiotik: Pemanfaatan Untuk Pakan Ikan Berkualitas Rendah. Media Akuakultur. Vol 3(2): 145-149.

Malaka, Ratmawati, dan A. Laga. 2005. 1solasi dan Identifikasi Lactobacillus Bulgaricus Strain Ropy dari Yoghurt Komersial. Jurnal Sains dan Teknologi. Vol 5(1):50-58.

Osawa. 2008. Osawa Sensei's Vibrio cholerae Isolation Protocol for Environmental Samples (Seafood and River or Melted Ice Water). Japan: KOBE University.

Rostini, I. 2007. Peranan Bakteri Asam Laktat (Lactobacillus plantarum) Terhadap Masa Simpan Filet Nila Merah Pada Suhu Rendah. Fakultas Perikanan dan Ilmu Kelautan. Universitas Padjadjaran. Jatinangor.

Suriawira, Unus. Drs. 1993. Mikrobiologi Air dan Dasar-dasar Buangan Secara Biologis. Penerbit Alumni. Bandung.

Syawal, H., Nasution, S., Ferdiansyah, R. 2016. Identifikasi Bakteri Patogen Di Perairan Waduk Koto Panjang Kabupaten Kampar Riau. Jurnal Ilmu Lingkungan. Pekanbaru. Vol. 10 (1).

Taher, nurmelita. 2010. Peningkatan Mutu Organoleptik Ikan Mujaer Itilapia Mosanbica) Segar Dengan Ukuran Yang Berbeda Selama Penyimpanan Dingin . Jurnal Perikanan dan Kelautan . vol VI no.1.UNSRAT.Manado 